\title{
Implementation of Switched Reluctance Motor using PWM Controlled Split Phase Converter in Hybrid
}

\author{
Anitha Sampath kumar, G. Hemavathi, .K. Dwarakesh
}

\begin{abstract}
This framework introduces the sun powered encouraged SRM by utilizing fluffy rationale framework. In this framework dc-dc converter, $K Y$ help converter is utilized to support the voltage from the PV board. Variable speed drives for $P V$-sustained electric vehicles demonstrate profoundly encouraging for financial and social development. Being increasingly affordable without winding and changeless magnets on rotor, exchanged hesitance engine (SRM) is raising as an alluring alternative in factor speed drives. Such a framework requests for an appropriate controller with basic and decreased parts. Established two switches for each stage converter is utilized to assess the execution of SRM .Performance attributes, for example, torque swell, speed and current of the SRM FUZZY rationale system is tried at different dimensions are displayed in this venture. Recreations were finished by utilizing Matlab/simulink programming. [19],[20],[21]
\end{abstract}

Keywords : converter,hybrid,switch

\section{INTRODUCTION}

Exchanged hesitance engine (SRM) is electromagnetic and electrodynamics hardware which changes over the electrical vitality into mechanical vitality. The electromagnetic torque is delivered on factor hesitance guideline. SRM utilizes Power semiconductor exchanging hardware Rotor position sensor. [1],[ 3],[5]

SRM is separately energized and doubly remarkable electrical engine. This implies it has remarkable shafts on both the rotor and the stator however the just a single part conveys winding. The rotor has no winding, magnets and confine twisting however it is work from a heap of striking post overlays development is straightforward and strong it requires less upkeep its general productivity is better it is adaptable control driving engine as motoring mode creating method of tasks of the machine can be effectively achieved. In the light of above it is an aggressive engine variable speed dc engine and variable speed 3 - stage confine enlistment engine.

\section{SIMPOWER SYSTEMS LIBRARIES}

The libraries include models of everyday strength tools, for example, transformers, traces, machines, and electricity

Revised Manuscript Received on August 22, 2019.

Anitha Sampathkumar, Department of EEE,Bharath Institute of Higher education and research, Tamilnadu, India. Email: anithababs@gmail.com

G.Hemavathi, Department of EEE,Bharath Institute of Higher education and research, Tamilnadu, India. Email: ghemadevi@gmail.com

K.Dwarakesh, Department of EEE,Bharath Institute of Higher education and research, Tamilnadu, India. Email: dwarakesh7281@ gmail.com gadgets. those fashions are displayed ones start from path books; andtheir validness depends upon the enjoy of the strength systems trying out and Simulation Laboratory of Hydro-Québec, a wide North American application prepared in Canada, what is extra at the enjoy of Evolve de technology ruling and Universities Laval. the bounds of SimPower systems for demonstrating an normal electric structure are plot in presentation records. Likewise, for customers who want to revive their comprehension into energy shape hypothesis, there are similarly selflearningcase investigates. The SimPower structures rule library, manipulate lib, makes its squares into libraries as indicated via their direct. The strength library window shows the square library pix and names. Twofold tap a library photograph to open the library and access the squares. The fundamental SimPower structures manage library window additionally consists of the effective rectangular that opens a graphical UI for the enduring country evaluation of electrical circuits. [2 ],[ 4],[6]

\section{PROPOSED SYSTEM SIMULATIONS:}

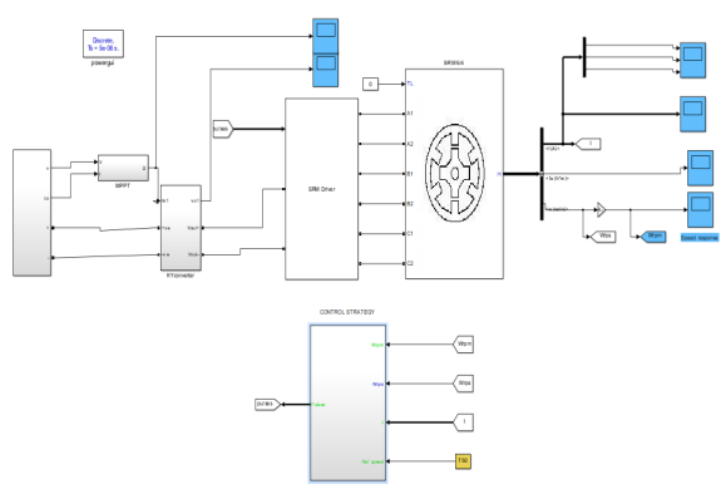

Two switch classical converter

Published By: Blue Eyes Intelligence Engineering \& Sciences Publication 


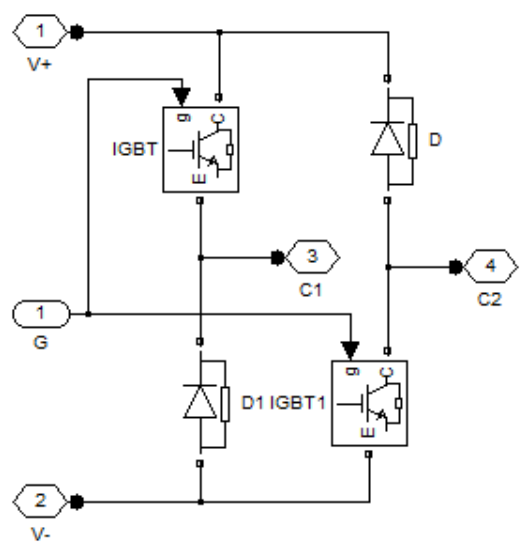

\section{Simulation Results}

The excitement show worked in Matlab/Simulink is utilized to consider both the PWM and SPM control at different detachment levels. Fig. 9(a) shows the reenacted PWM and SPM system at 0.2 security $(1372 \mathrm{rpm})$ with Ton= - $3.75 \mathrm{deg}$ and Toff as $11.25 \mathrm{deg}$. If there should arise an occurrence of SPM Ton is changed and MPPT at different security levels.

\section{ELECTRICAL CIRCUIT WITH SIMULINK}

The Voltage dimension square goes about as an interface between the SimPowerSystemsblocks and the Simulink squares. For the framework seemed, you achieved such an interface from the electric structure to the Simulink structure. The Voltage size square changes over the cognizant voltages into Simulink alerts. for example, you could make use of the managed Voltage supply square to instill a voltage in an electrical circuit, as regarded inside the going with discern. [19],[20],[21]

\section{MEASURING VOLTAGES AND CURRENTS}

whilst you degree a present utilising a current size baffle, the positive heading of modern-day is shown at the rectangular photograph (advantageous contemporary spilling out of + terminal to - terminal).in addition, while you degree a voltage utilizing a Voltage measurement impede, the cognizant voltage is the voltage of the + terminal as for the terminal. anyhow, while voltages and surges of squares from the elements library are evaluated utilizing the Millimeter baffle, the voltage and modern polarities aren't speedy obvious in mild of the way in which that squares can also had been circled and there aren't any signs indicating polarities at the rectangular pix. [8],[10],[12]

\section{CONNECTING CAPACITORS AND INDUCTORS}

Right when capacitor portions are associated together with voltage sources, or inductor parts in blueprint with current sources and when the age is begun, SimPower Systems will flag a misunderstanding in the event that one of the going with two connection botches are open in your chart. [13], [15] ,[ 17]
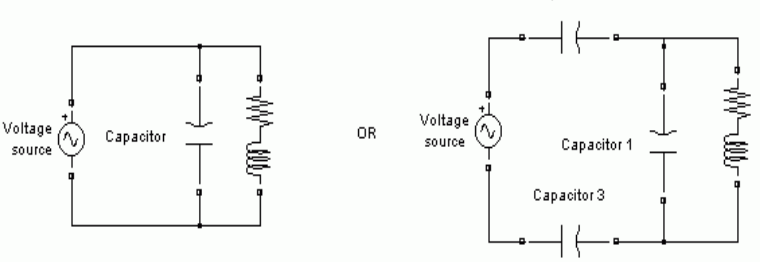

Right when a present source in strategy with an inductor, or a development of inductors related in parallel, as in the model underneath, an enormous hindrance must be joined parallel with the inductor and the capacitors. [7],[ 9] ,[11]

\section{EXISTING RESULT:}

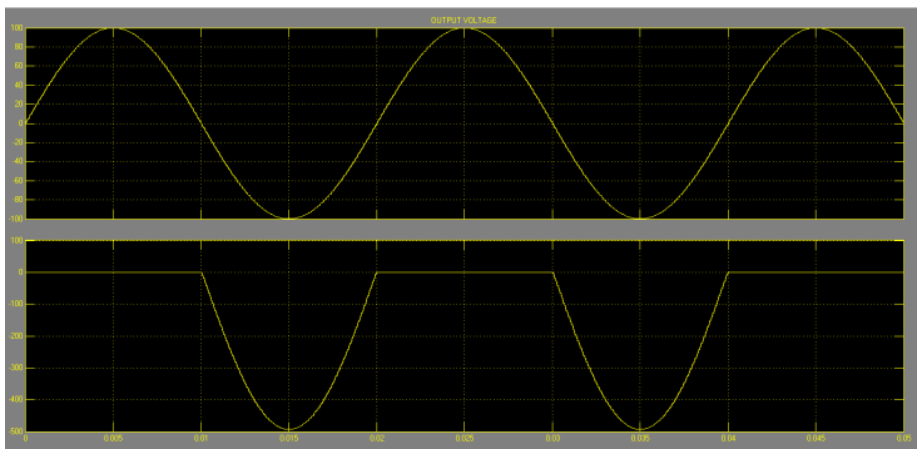

\section{PROPOSED RESULT}

Speed waveform:

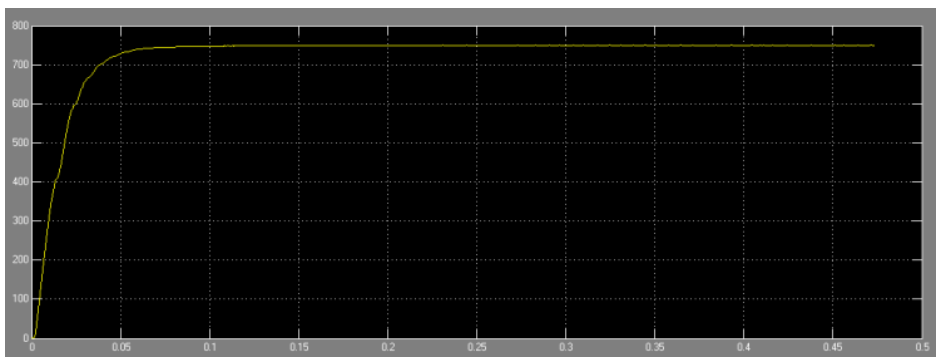

Current waveform:

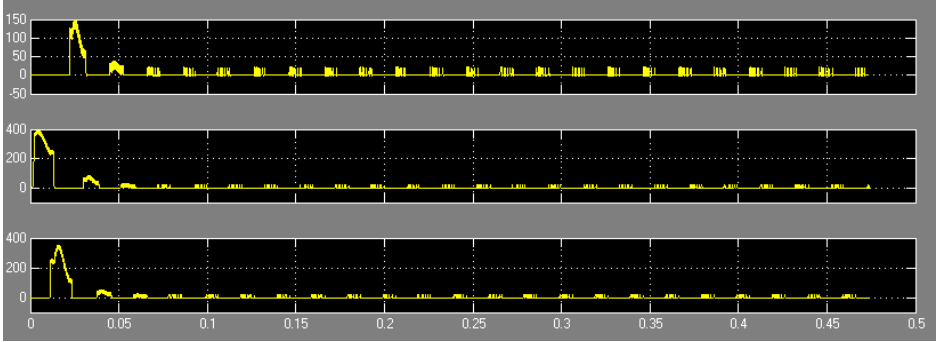

simulation and experimental comparison of section top

Torque waveform:

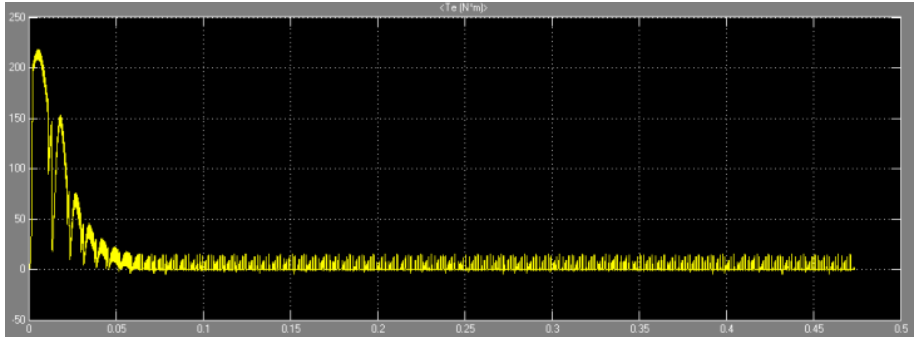

Torque ripple comparison of PWM and SPM at diverse insulation levels

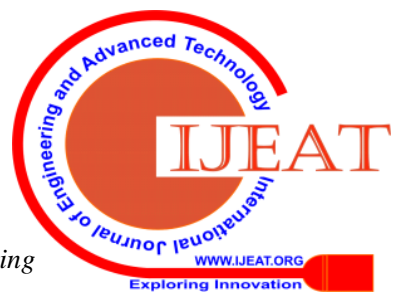




\section{Conclusion}

The quality fragment performs critical employment inside the power machine, to advancement the capability of the power machine we did the power point of view cure, in our assignment the we executed the 3 stage info power portion change in accordance with improvement the efficiency of the quality machine, with the guide of using the diversion check and affirm the result and besides we complete in the gear check and last item are endorsed. [14],[ 16], [18].

\section{REFERENCES}

[1] Sharma, R.K., Irusapparajan, G. \& Periyaazhagar, D. 2019 "Three-phase symmetric cascading Z-source seven levels multilevel inverter excited by multi carrier sinusoidal pulse width modulation scheme", International Journal of Innovative Technology and Exploring Engineering, vol. 8, no. 10, pp. 4269-4274.

[2] Velavan, R., Bharanidharan, S. \& Sheeba, B. 2019, "EMF pollution Causes, effects and protection", International Journal of Innovative Technology and Exploring Engineering, vol. 8, no. 9 Special Issue 3, pp. 1166-1168.

[3] Saravana, S., Balaji, S., Arulselvi, S. \& John Paul Praveen, A. 2019, "Reliable power quality monitoring and protection system", International Journal of Innovative Technology and Exploring Engineering, vol. 8, no. 9 Special Issue 3, pp. 644-645.

[4] Tamil Selvan, S. \& Sundararajan, M. 2019, "Performance Parameters of 3 Value 8t Cntfet Based Sram Cell Design Using H-Spice", International Journal of Recent Technology and Engineering, vol. 8, no. 2 Special issue 5, pp. 22-27.

[5] Jac Fredo, A.R., Abilash, R.S., Femi, R., Mythili, A. \& Kumar, C.S. 2019, "Classification of damages in composite images using Zernike moments and support vector machines", Composites Part B: Engineering, vol. 168, pp. 77-86.

[6] Kathiravan, P. \& Govindaraju, C. 2019, "Design and evaluation of ultra gain isolated DC-DC converter for photovoltaic system", International Journal of Engineering and Advanced Technology, vol. 8, no. 5, pp. 2646-2651.

[7] Kripa, N., Vasuki, R. \& Kishore Kanna, R. 2019, "Realtime neural interface controlled au-pair BIMA bot", International Journal of Recent Technology and Engineering, vol. 8, no. 1, pp. 992-994.

[8] Mohanraj, Meenaa Kumari, M., Philomina, S. \& Jasmin, M. 2019 , "In-situ humidity measurement of hydrogen fuel cell car using MEMS sensor", International Journal of Recent Technology and Engineering, vol. 8 , no. 1, pp. 41-43.

[9] Velmurugan, T. \& Prakash, S. 2019, "Artificial intelligent based distribution automation of swift fault detection isolation and power restoration for HT network", International Journal of Innovative Technology and Exploring Engineering, vol. 8, no. 6, pp. 1-6.

[10] Dwarakesh, K. \& Prem Kumar, G. 2019, "Five-level inverter based sequential boost system using fuzzy logic controller", International Journal of Innovative Technology and Exploring Engineering, vol. 8, no. 6, pp. 12-19.

[11] Anne Gifta, A. \& Hemavathi, G. 2019, "Analysis of grid tied solar PV system using ANFIS Algorithm", International Journal of Innovative Technology and Exploring Engineering, vol. 8, no. 6, pp. 312-316.

[12] Jayavel, R., Rangaswamy, T.R. \& Prakash, S. 2019, "Efficient grid management system with renewable and conventional power sources", International Journal of Innovative Technology and Exploring Engineering, vol. 8, no. 6, pp. 287-289.

[13] Hemavathi, G. \& Maheshwaran, S. 2019, "Proportional resonant controlled high gain step-up converter system with improved response", International Journal of Innovative Technology and Exploring Engineering, vol. 8, no. 6, pp. 317-323.

[14] Periyaazhagar, D. \& Irusapparajan, G. 2019, "Design and completion of asymmetric single phase 27 level cascaded mli for various pwm scheme", International Journal of Innovative Technology and Exploring Engineering, vol. 8, no. 6, pp. 792-797.

[15] Mahalakshmi, V. \& Vijayaragavan, S.P. 2019, "PV based power electronic converters for high voltage DC applications", International Journal of Recent Technology and Engineering, vol. 7, no. 6, pp. 670-674.

[16] Irusapparajan, G., Periyaazhagar, D., Prabaharan, N. \& Rini Ann Jerin, A. 2019, "Experimental verification of trinary DC source cascaded h-bridge multilevel inverter using unipolar pulse width modulation", Automatika, vol. 60, no. 1, pp. 19-27.
[17] Sangeetha, G., Sherine, S., Arputharaju, K. \& Prakash, S. 2019, "On Line Monitoring of Higher Rated Alternator using Automated Generator Capability Curve Administer", Proceedings of the IEEE International Conference on \&amp;quot;Recent Trends in Electrical, Control and Communication\&amp;quot;, RTECC 2018, pp. 176.

[18] Bycil, V.J. \& Wiselin, M.C.J. 2019, "Modeling and analysis of vibration energy harvesting system using piezo stack", International Journal of Mechanical and Production Engineering Research and Development, vol. 9, no. Special Issue 1, pp. 523-533.

[19] Sripada, A., Warrier, A., Kapoor, A., Gaur, H. \& Hemalatha, B. 2018, "Dynamic lateral balance of humanoid robots on unstable surfaces", International Conference on Electrical, Electronics, Communication Computer Technologies and Optimization Techniques, ICEECCOT 2017, pp. 539.

[20] Srinivasan, S., Thirumalaivasan, K. \& Sivakumaran, T.S. 2018, "Performance evaluation of double-output luo converters", Journal of Advanced Research in Dynamical and Control Systems, vol. 10, no. 10 Special Issue, pp. 870-878.

[21] Karthikayen, A. \& Selvakumar Raja, S. 2018, "A skellam distribution inspired trust factor-based selfish node detection technique in MANETs", Journal of Advanced Research in Dynamical and Control Systems, vol. 10, no. 13, pp. 940-949.

\section{AUTHORS PROFILE}

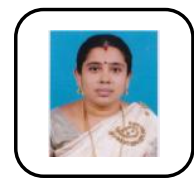

Anitha SampathKumar, Assistant Professor Department of EEE, Bharath Institute of Higher Education and Research, Tamilnadu, India.

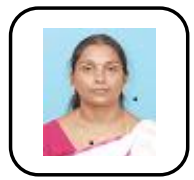

G.Hemavathi, Assistant Professor Department of EEE, Bharath Institute of Higher Education and Research, Tamilnadu, India.

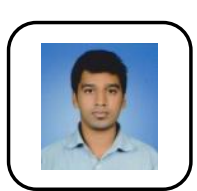

K.Dwarakesh, Assistant Professor ,Department of EEE Bharath Institute of Higher Education and Research, Tamilnadu, India. 